\title{
Research of clean drinking water provision the population of the Kemerovo region-Kuzbass
}

\author{
Anna Zaytseva ${ }^{1, *}$, Olga Brel $^{1}$, and Kirill Makarov ${ }^{1}$ \\ ${ }^{1}$ Kemerovo State University, 650000, Krasnaya Street, Kemerovo, Russia
}

\begin{abstract}
Many regions of Russian Federation have serious problems with water supply. Despite the significant water resource potential, including ground, surface and mineral waters, not all the population of the Kemerovo region is provided with clean drinking water. Besides the location of heavy industry enterprises, especially coal mines and pits, within the boundaries of river basins affects the condition and quality of water from different water sources. The purpose of this paper is to provide a research of clean drinking water providing the population of the Kemerovo region-Kuzbass, formulate the main problems and identify possible areas of activity in the field of increasing the availability of clean drinking water for the population of Kemerovo region-Kuzbass.
\end{abstract}

\section{Introduction}

Safe and accessible water is an important factor in human health, regardless of the purposes for which it is used (drinking, domestic needs, cooking, etc.). An improved water supply and sanitation system and more efficient water use can contribute to economic growth in countries and make a significant contribution to poverty reduction. Improved water supply and sanitation system and more efficient water management can contribute to economic growth of countries and make a significant contribution to poverty reduction.

One of the most important areas of socio-economic development of the Russian Federation is the provision of its population with clean drinking water. The results of analysis and assessment of drinking water availability are covered in the state reports through the indicators of availability of water sources and technical condition of the centralized water supply system.

According to [1], in 2019, 85.5\% of the population of the Russian Federation was provided with clean drinking water. However, the target indicator for the same year was $87.5 \%$. This situation is explained by the fact that in 32 constituent entities of the Russian Federation the specified base values of this indicator were not achieved. $93.2 \%$ of city residents were provided with safe drinking water. This is also below the target level for this year $(94.5 \%)$.

In 2019 only in 40 out of 85 constituent entities of the Russian Federation the share of urban population provided with quality drinking water from centralized water supply systems was at or exceeded the 2019 target (94.5\%) [1].

\footnotetext{
*Corresponding author: lit-ani@mail.ru
} 
The other regions of Russia have serious problems with water supply. The reason for this is the extremely uneven distribution of surface water resources over the territory of the country, their great temporal variability (especially in the southern regions), and a high degree of pollution. The lowest share of urban population provided with quality drinking water from centralized water supply systems was observed in the Republic of Kalmykia $(0.0 \%)$, the Republic of Tyva (40.3\%), Trans-Baikal Territory (59.1\%), the Vologda Region $(62.6 \%)$ and the Nenets Autonomous District (67.3\%).

A comparative analysis of water quality indicators of surface and underground sources of centralized water supply network shows that the water of surface sources is better than underground sources in terms of sanitary and chemical indicators, but worse in terms of microbiological indicators. The quality and safety of drinking water as a set of indicators characterizing its physical, chemical, bacteriological, organoleptic and other properties is affected not only by the degree of pollution of centralized water supply sources, including due to the lack of sanitary protection zones, but also the condition of the water supply and distribution network [1].

\section{Materials and methods}

The problem of providing the population of the regions of the world is widely covered in the researches of domestic and foreign scientists. Their papers are mainly devoted to the role of national and municipal authorities in water security, water supply and sanitation [2, 3]. The approaches to assessment of water delivery in the municipalities are also presented. A large number of works are devoted to the study of these problems in African and Asian countries $[4,5]$. But this challenge concerns Russia and its regions.

The Kemerovo Region has a significant water resource potential, including ground, surface and mineral waters. They create the necessary prerequisites for the development and location of industry and other sectors of the regional economy.

Groundwater in the Kemerovo region belongs to the hydrogeological structures of the Altai-Sayan complex hydrogeological folded region (in particular the Sayan-Tuva hydrogeological folded region and the Altai-Tomsk hydrogeological massif) and the West Siberian complex artesian basin (in particular the Irtysh-Obsk artesian basin) [6]. The natural state of groundwater in the Kemerovo region is characterized by hardness and increased content of iron and manganese. Such factors as coal mining, metallurgical and chemical production, agriculture, transportation, human activities, household dumps and man-made dumps, etc. have a significant impact on the quality of groundwater in the Kemerovo region.

Novokuznetsk, Kemerovo, Belovo, Prokopyevsk and Yaisky districts and the city of Novokuznetsk are the most provided with the forecasted operational resources of groundwater. Groundwater reserves in these territories are more than 76 thousand $\mathrm{m}^{3}$ per day (Fig. 1). 


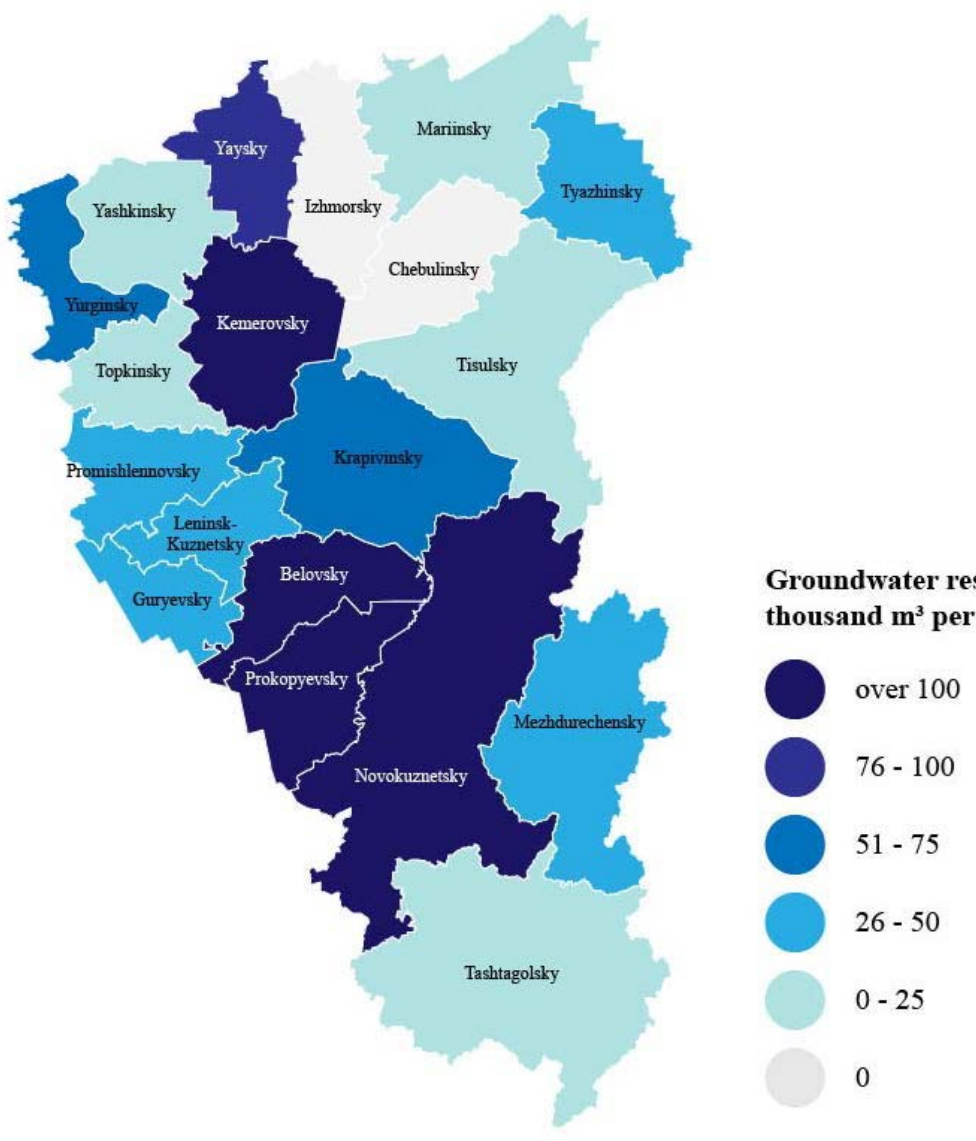

Fig. 1. Map-scheme "Groundwater reserves (fresh and brackish) by administrative units of the Kemerovo region as of 01.01.2019" [according to FSBI "Gidrospetsgeologiya"].

Groundwater sources are considered unprotected and conditionally protected from surface pollutants. At present, about 3,900 wells are in operation in the Kemerovo region. Most of them do not have a sanitary protection zone or livestock farms, filtration fields and landfills are located on their territory. The condition of water sources and water supply networks, lack of proper control over the depletion and quality of water - all these factors affect the provision of quality drinking water to the population Oil products, phenols, heavy metals, sulfates, chlorides, and nitrogen compounds prevail are among groundwater pollutants [7].

Mineral groundwater reserves amount to 0.235 thousand $\mathrm{m} 3 /$ day. Three mineral water deposits - Tersinskoe, Borisovskoe, Berezovoyarskoe - have been explored and operated currently in Kuzbass. Their total reserves are 0.235 thousand $\mathrm{m} 3 /$ day. Barzasskoe mineral water manifestation has been revealed within the region.

The water supply of the Kemerovo Region is mainly provided by surface water. Fresh water intake from surface water bodies exceeds the intake from underground water by 3-4 times [6]. The surface waters are represented by numerous rivers, lakes, swamps and reservoirs. The greatest socio-economic importance among surface waters belongs to rivers Tom, Inya, Chulym and Chumysh. They are the first order tributaries of the Ob River. Tom is the main water artery of Kuzbass. Its length is $827 \mathrm{~km}$. 
On the territory of the Kemerovo region, within the boundaries of river basins, industrially loaded areas with enterprises of coal, metallurgical and chemical industries are situated, which affects the condition and quality of water. Long-term wastewater discharges, $27.33 \%$ of which are untreated or insufficiently treated and decontaminated, have adversely affected the self-cleaning capacity of rivers.

The Tom river basin is of the greatest importance in water use and assessment of water pollution in the Kemerovo region. The largest share in the overall assessment of the degree of water pollution in the area below Novokuznetsk (the middle reaches of the Tom) is made by nitrite nitrogen, volatile phenols, total iron, manganese, oil products. The most polluted tributaries of the Tom are the Inya and Kondoma rivers. Their water pollution class refers to 4 "A" and 3 "B" - from dirty to very contaminated (Fig. 2).

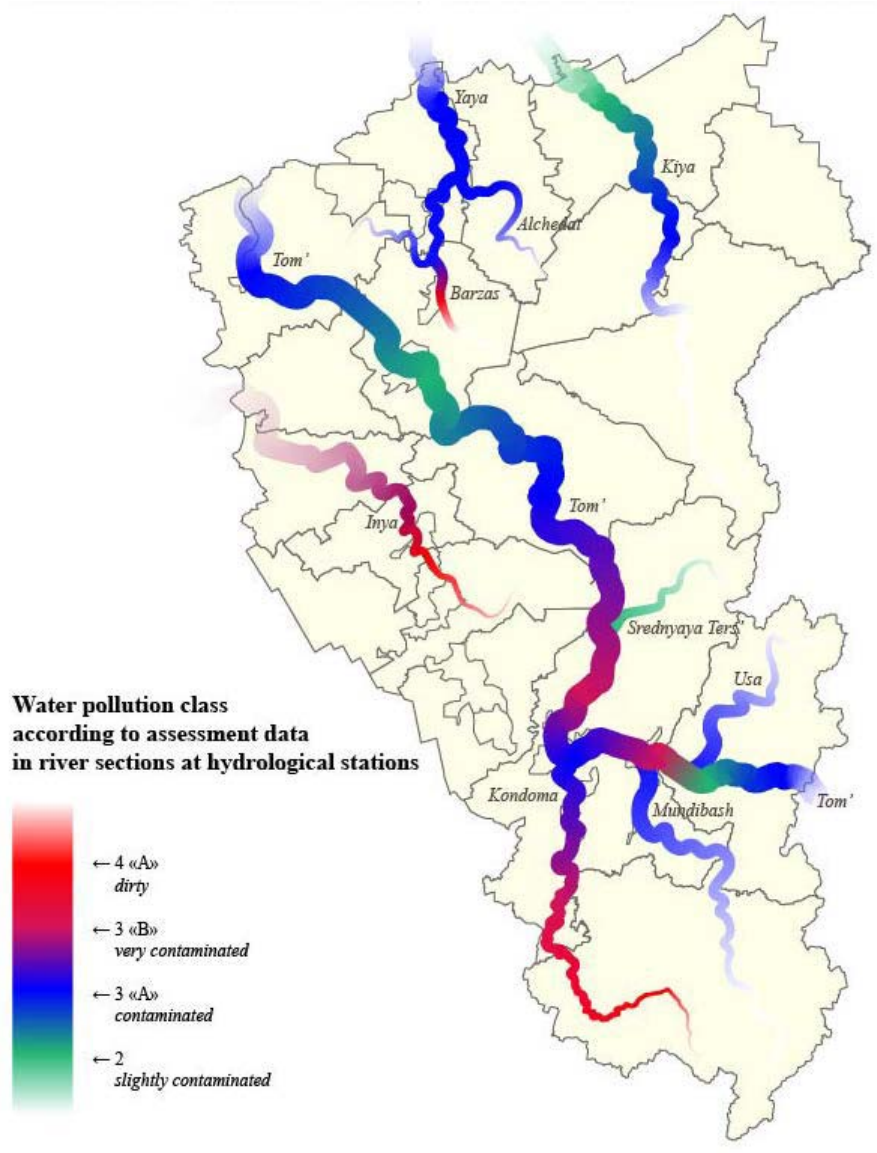

Fig. 2. Map-scheme "Water pollution class of some rivers of Kemerovo region in 2019" [according to the Kemerovo Center for Hydrometeorology and Environmental Monitoring (branch of the West Siberian Department for Hydrometeorology and Environmental Monitoring)].

Many small rivers have turned into appendages of the sewer system (for example, the Aba River) [8]. The economic capacity of ecosystems has already been exceeded in a large part of the Kemerovo region. Further increase in production will lead to catastrophic degradation of the natural environment, complete depletion of the resource base and reduction of the quality of life of the local population. The main pollutants of surface waters are oil products, phenols and nitrogen-containing compounds. 
Pollution of surface and ground water, lack of drinking quality water, low efficiency of water treatment facilities, massive development of water protection zones, non-compliance with regulations of economic activities in the zones of sanitary protection of drinking water supply sources, poor sanitary and technical condition of distribution network - all of these create a tense situation in providing drinking water to the region's population.

\section{Results}

Despite the high level of industrial development, $98.3 \%$ of the inhabitants of the Kemerovo region have access to high-quality drinking water. This figure has not changed compared to the previous year. Among the total population provided with quality drinking water, $98.4 \%$ are the urban population $(+4.4 \%$ by 2018$)$ [6].

The quality of drinking water is evidenced by water samples taken from surface and underground sources of centralized and non-centralized water supply for their compliance with sanitary requirements for sanitary-chemical and microbiological indicators.

Approximately one third of water samples taken from surface and underground sources of centralized water supply did not meet sanitary requirements for sanitary-chemical and microbiological indicators in 2019 (Fig. 3).

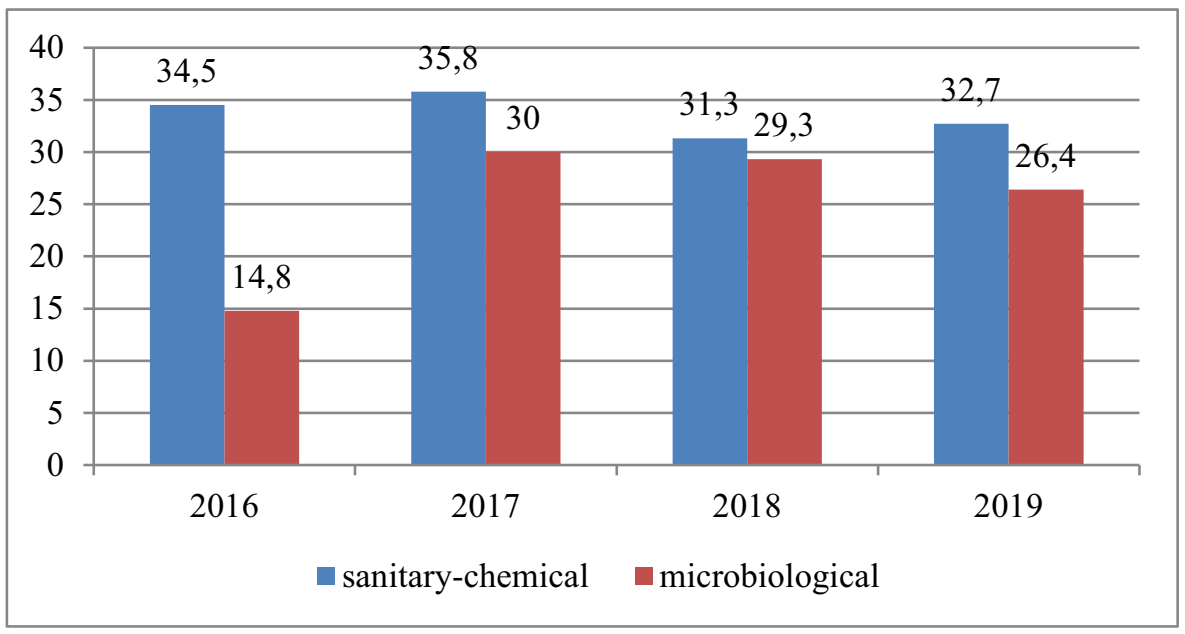

Fig 3. Share of water samples from centralized water supply sources that do not meet the requirements for sanitary-chemical and microbiological indicators, $\%$ [9].

Over the past four years, the share of water samples that do not meet the requirements for sanitary and chemical indicators has changed slightly $(-1.8 \%$ by 2016$)$, while the share of microbiological indicators has almost doubled $(+11.6 \%)$.

In 2019, the average share of water samples from surface sources of centralized water supply that did not meet hygienic requirements was $47.9 \%$ for microbiological indicators and $24.1 \%$ for sanitary and chemical indicators. This indicator exceeded the average value for microbiological parameters in 3 administrative territories of the region (cities of Kemerovo, Novokuznetsk, Jurga) and for sanitary and chemical indicators in 11 administrative territories (cities of Taiga, Kemerovo, Osinniki, Novokuznetsk, Myski, Jurga; districts: Leninsk-Kuznetsky, Novokuznetsky, Jurginsky, Yaysky, Yashkinsky).

The share of water samples from underground sources of centralized water supply that do not meet the sanitary requirements according to microbiological parameters exceeded the average regional indicator of 3.2\% in 6 administrative territories (the city of Myski; disctricts: Kemerovo, Mariinsky, Novokuznetsk, Tyazhinsky, Yurginsky). And according 
to the average regional sanitary and chemical indicator of $36.7 \%$ it exceeded in 6 administrative territories (disctricts: Leninsk-Kuznetsky, Novokuznetsk, Prokopyevsky, Yurginsky, Yaysky, Yashkinsky).

A serious problem affecting the providing the population by clean drinking water is the physical deterioration of regional water supply networks $(52.01 \%)$, water intake facilities $(60.45 \%)$, water treatment facilities $(49.19 \%)$ and water pumping facilities $(35.09 \%)$.

For solving the problem of providing the population of Kemerovo region with clean drinking water, water supply facilities use appropriate technologies for water purification and disinfection taken from sources of centralized water supply. Classic schemes for cleaning and disinfecting tap water (water clarification using settling tanks and rapid filters, application of coagulants and flocculants, water disinfection with sodium hypochlorite) are used in Novokuznetsk, Mezhdurechensk, Osinniki, Prokopyevsk, Kiselevsk, Kemerovo, Yurga, Anzhero-Sudzhensk, Tashtagol, Berezovsky.

Before being supplied to the distribution network of settlements, ground water is subjected to appropriate treatment (depellation, demanganation, softening, aeration, clarification) and decontamination. However, a number of water supply structures of the Kemerovo region do not have the necessary complex of water purification facilities from centralized water supply sources to drinking quality. The most difficult situation with the availability of a complex of treatment facilities is noted in Krapivinsky (63.3\% of all water pipelines do not have systems to purify water to drinking quality) and Kemerovsky (47.9\% of water pipelines do not have systems to purify water to drinking quality) districts.

Despite the problems, the quality of tap water from the Kemerovo region distribution network has a significant trend towards improvement in terms of sanitary-chemical and microbiological indicators over the past 6 years (Fig. 4).

Thus, in 2019, the share of water samples from the distribution network of centralized water supply that did not meet hygienic standards for sanitary and chemical indicators was $7.9 \%$ (- $3.8 \%$ vs. 2015$)$ and $1.7 \%$ for microbiological indicators (0,3\% vs. 2015$)$.

The condition of drinking water from non-centralized water supply sources has also been improving in recent years. In 2019 the share of non-centralized sources of drinking water supply, not meeting sanitary and epidemiological requirements on both groups of indicators was $23,7 \% \quad(-1,8 \%$ vs. 2018). Non-compliance of water with sanitary requirements on parasitological indicators was also not detected.

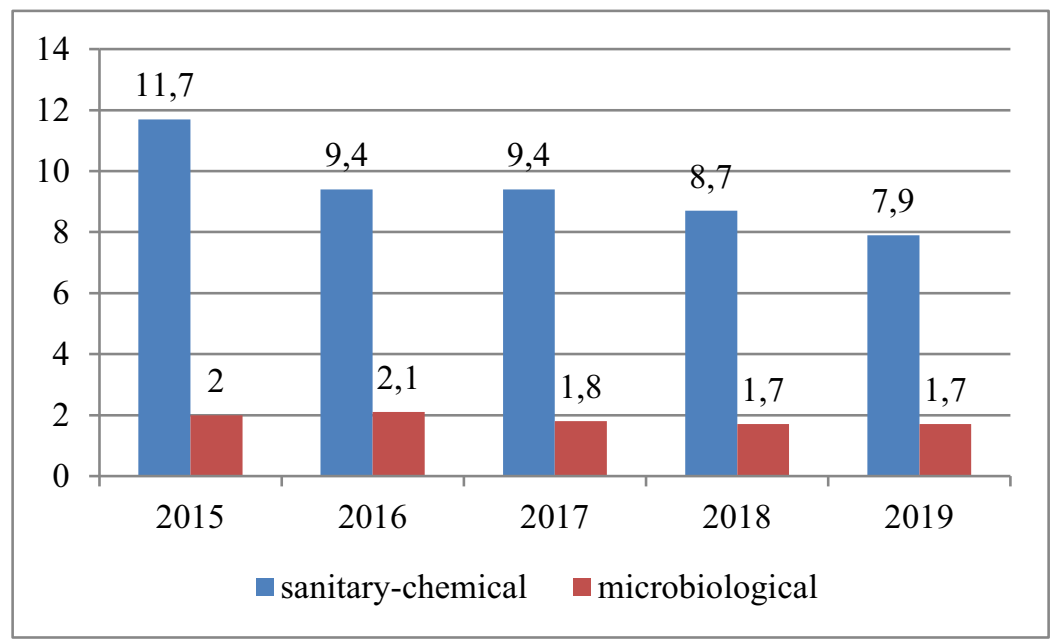

Fig. 4. Share of water samples from the distribution network of centralized water supply that do not meet sanitary-chemical and microbiological indicators, \% [9]. 
A comparative assessment of water samples from centralized and non-centralized water supply sources leads to the conclusion that the biggest problem for water from both types of water supply source is its non-compliance with hygienic standards for sanitary and technical indicators. Besides poor water quality from non-centralized sources is more associated with the presence of pathogenic microorganisms, which can lead to negative consequences, among which the most dangerous is the risk of occurrence and development of acute intestinal infections dysentery, viral hepatitis, infectious diseases.

The problem of drinking water quality is closely related to its accessibility for some groups of the population living in some areas of Kemerovo region (Fig. 5). The low availability of drinking water for residents of the areas shown in the picture and its noncompliance with the requirements of regulatory documents is not due to limitations of this benefit, but due to shortcomings of water management system and use of the resource of shared consumption.

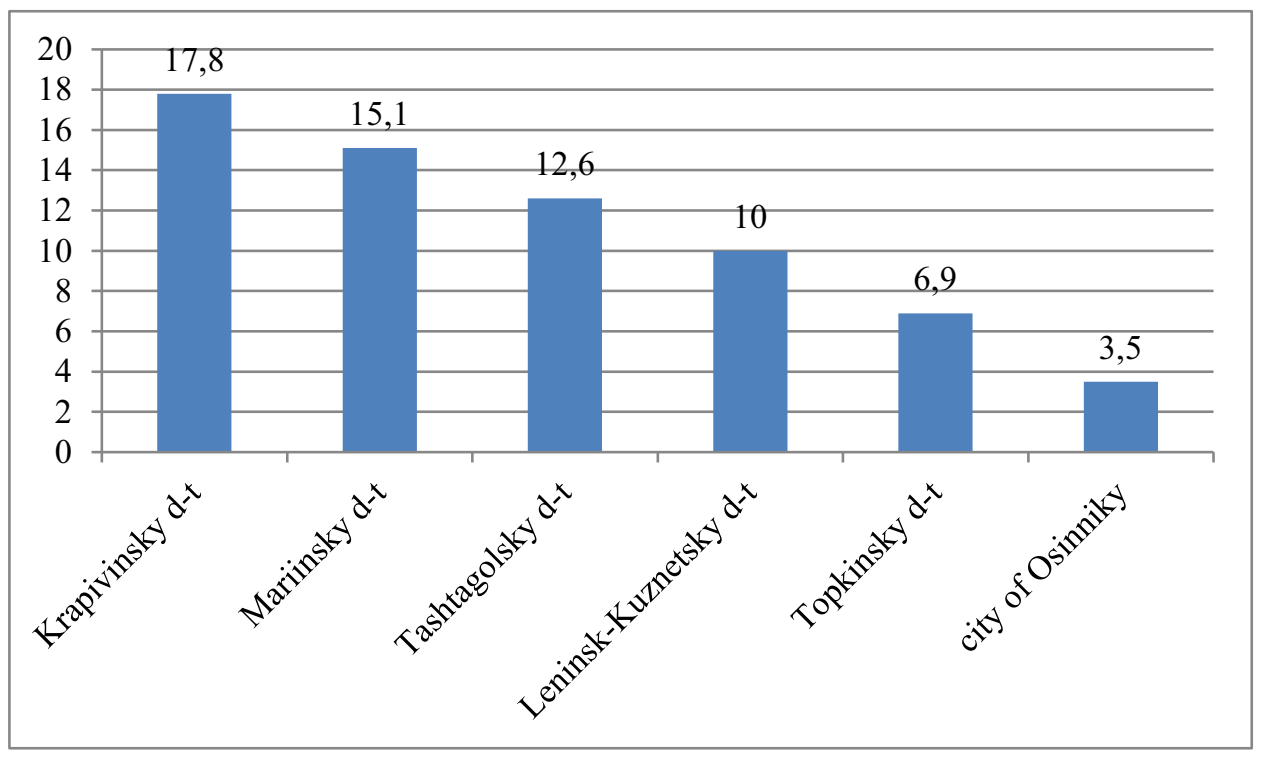

Fig. 5. The number of population receiving drinking water that does not meet the quality and harmlessness indicators, thousand people [9].

In the Kemerovo region activities aimed at reducing the negative impact of water, increasing the availability and improving the level of provision of quality drinking water are carried out currently. They include measures for clearing the channels of water bodies, as well as measures aimed at reducing anthropogenic pollution of water bodies - such as the construction and reconstruction of treatment facilities, cleaning of water protection zones of water bodies, monitoring of water bodies, stocking of reservoirs, etc.

Modern technologies of polluted surface waters treatment are actively implemented in Kuzbass. Among them are a two-stage scheme with clarification and filtration on highspeed filters, the use of effective reagents coagulant - aluminum oxychloride (OXA) and flocculant - "Praestol 650TR". Water disinfection is performed by joint application of UV irradiation and sodium hypochlorite. To reduce organochlorine compounds and prolong the bactericidal properties of chlorine in the water distribution network, water ammonification is provided. It allows reducing the dose of chlorine by $20-30 \%$ [10].

Traditional institutional arrangements are another way of solving the problem of water pollution. Water tax, standard and excess water use fees, and fines for environmental violations are among these tools. Unfortunately, these tools are economically effective only 
when it comes to the recovery of manufacturing costs or pollution-related environmental and resource costs. These measures are unlikely to improve the access to quality water resources [11].

Strategic water reserves are needed to ensure the water security of the Kemerovo region and increase the level of drinking water supply to the population. In order to improve water quality and provide a backup water supply to settlements in case of emergencies a significant increase in the use of groundwater is planned. This applies primarily to major cities (Kemerovo, Novokuznetsk) that use water from surface water sources. It is planned to conduct an inventory of underground water intakes, improving the design of water intake wells, filters, lifting equipment, as well as implementation a set of measures for protecting underground water from depletion and pollution.

In accordance with the goal of the regional project "Clean Water" it is expected to provide $99 \%$ of the region's population with high-quality drinking water by 2024 .

The implementation of the measures outlined in this program is possible through the provision of federal subsidies to local budgets for co-financing measures for the construction, reconstruction (modernization) of drinking water supply facilities owned by the municipality.

\section{Discussion}

The results of the analysis of clean drinking water providing the population of the Kemerovo region-Kuzbass allow us to formulate the following main problems:

1. A significant number of administrative territories of Kuzbass have poor quality drinking water supply because of: unsatisfactory sanitary and technical condition of water supply networks (water treatment plants have a wear of 50 to $95 \%$ ); absence of treatment facilities in a number of administrative territories or the discrepancy between the water treatment technology and the water quality of the water source; lack of sanitary protection zones for water sources. The share of water pipes that do not have sanitary protection zones ranges from $8.5 \%$ to $94 \%$.

2. Some administrative territories of Kemerovo region-Kuzbass have lack of uninterrupted drinking water supply, especially in summer, due to low head, lack of water supply on the upper floors of high-rise buildings in case of emergencies, low efficiency of water distribution networks, etc.

3. Partial or complete absence of centralized water supply in certain territories, primarily rural ones. People use water from standpipes located in the zones of centralized water supply systems, springs, individual wells, mine wells and rivers for household and drinking purposes.

4. Lack of registration of water supply facilities ownership: non-centralized water supply sources are not registered with the territorial department of Rospotrebnadzor and often have water that does not meet current standards.

5. Low degree of automation of production processes of water supply to the population of same territories.

6. Large losses of water in water pipelines and distribution networks during its transportation due to the significant removal of water intake and water treatment facilities from consumers.

\section{Conclusions}

The results of the analysis of the above-mentioned problems allow us to determine possible areas of activity in this field and points of further growth: 
- guaranteed provision of water resources to the population and brunches of Kuzbass economy

- creation of an effective management system for the use and protection of water bodies and provision of drinking water to the population of the region;

- taking into account water resource restrictions and the permissible ecological load on water bodies;

- modernization and expansion of existing industrial capacities with the simultaneous introduction of systems of recycled and re-sequential water supply, ensuring the rational use of available water resources, as well as reducing the anthropogenic load on water bodies;

- increasing the use of surface water bodies for the needs of household and drinking water supply;

- using of modern treatment facilities and applying highly effective innovative technologies for the preparation of new-generation drinking water, supplemented by the processes of ozonation and sorption on activated carbon;

- elimination of the influence of seasonal changes in the quality of natural water through the use of the latest technologies;

- organization and arrangement of sanitary protection zones for drinking water supply sources;

- introduction of water-saving technologies to increase the level of provision of drinking water to the population;

- economic incentives to reduce specific water consumption and unproductive water losses during transportation and use;

- $\quad$ optimization of the amount of consumed water by equipping all groups of consumers with metering systems;

- reducing the drinking water consumption for production and landscaping needs.

Providing the population of the Kemerovo region with quality drinking water through these and other measures should be among the priorities for improving the quality of life and living environment of the population of Kemerovo region-Kuzbass.

\section{References}

1. On the state of sanitary and epidemiological well-being of the population in the Russian Federation in 2019: State report, https://www.rospotrebnadzor.ru/documents/details.php?ELEMENT_ID=14933

2. M. García, M. Hileman, Ö. Bodin, A. Nilsson, and P.R. Jacobi, Ecology and Society 24(1), 28 (2019) https://doi.org/10.5751/ES-10793-240128

3. Enhancing inter-municipal cooperation for water supply and sanitation (2012) https://www.oecd.org/env/outreach/UKR\%20IMC_intern\%20exp.pdf

4. Water Supply and Sanitation in South Africa Environmental Rights and Municipal Accountability (LHR Publication Series, 2009) https://cer.org.za/wpcontent/uploads/2011/11/LHR-DBSA_Water_Report.pdf

5. A. Jimenez, F. Mtango, S. Caincross, Water Policy 16(6), 1104-1120 (2014) https://doi.org/10.2166/wp.2014.203

6. O. Brel, G. Zadorozhnaya, N. Sasaev, A.I. Egorova, Russian J. of Industrial Economics 13(3), 357-365 (2020) DOI: 10.17073/2072-1633-2020-3-357-365

7. K. Zacharina, A. Aleksandrovich, Russian J. of resources, conservation and recycling 4(4) (2017) DOI: 10.15862/08RRO417 
8. T. Shimko, V. Voronin, M. Tsarev, Russian J. of Industrial Economics 13(3), 366-374 (2020) DOI: 10.17073/2072-1633-2020-3-366-374

9. On the state of sanitary and epidemiological well-being of the population in the Kemerovo region in 2019: State report, http://42.rospotrebnadzor.ru/content/813/94896/

10. V. Kvint, Strategizing of Kuzbass region water resources (Kemerovo, Russia, 2021)

11. A. Antonova, Y. Zheleznov, IOP Conf. Series: Earth and Environmental Science 666, 062057 (2021) DOI:10.1088/1755-1315/666/6/062057 